\title{
SEGATO, RITA LAURA. LA NACIÓN Y SUS OTROS: RAZA, ETNICIDAD E DIVERSIDAD RELIGIOSA EN TIEMPOS DE POLÍTICAS DE LA IDENTIDAD. BUENOS AIRES: PROMETEO, 2007.
}

Daniel Alves

A influência do multiculturalismo exacerbado sobre a teoria da globalização tem acarretado problemas analíticos. As críticas de antropólogos e sociólogos às teorias do sistema mundial têm obscurecido o fato de que os fluxos transnacionais de bens e ideias não são desordenados. Circuitos mundiais de bens e ideologias são absorvidos de forma heterogênea nos contextos locais, porém seus itinerários e apropriações são influenciados pelas assimetrias de poder entre nações. Esses dois aspectos estão fundidos no que Rita Laura Segato denomina formações nacionais de alteridade, conceito-chave de interpretação ao longo de todo o livro La nación y sus otros, que traz um conjunto de onze artigos publicados pela professora da UnB nos últimos anos, precedidos de uma introdução retrospectiva.

Cabe aqui dizer que a antropóloga em questão é referência importante no estudo da difusão das religiões afro-brasileiras e pentecostais na Argentina. Nos últimos anos, Segato engajou-se num debate público acerca de direitos étnicos no Brasil, sendo uma das intelectuais mais ativas a favor do sistema de cotas universitárias para afrodescendentes, sem prescindir de posicionamentos críticos em relação a esse processo. Desde seus dois artigos de 1991 sobre religião, que figuram como os capítulos sétimo e oitavo do recente livro, até as discussões mais recentes sobre raça e políticas da diversidade, apresenta-se como linha geral de análise a relação desses objetos com a constituição da nacionalidade.

No primeiro e sexto capítulos, é desenvolvida uma comparação ampla entre Argentina, Brasil e Estados Unidos, tendo como parâmetro as formas através das quais a identidade nacional se constituiu tendo como espelho "outros" a serem negados. A formação nacional da alteridade argentina se assemelharia mais ao

* Doutorando em Antropologia - Universidade Federal do Rio Grande do Sul 
modelo francês, segundo a autora, pois se constituiu a partir da elite intelectual bonairense que, no século XIX, estabeleceu a identidade nacional como anteposta a todas e quaisquer diferenças internas, em meio à enxurrada de população estrangeira vinda da Europa e ao extermínio das populações indígenas. As racionalizações e ritualizações do "ser argentino" impuseram-se sobre a diversidade da população, instiladas tanto pela violência militar, quanto pelos aparatos estatais de educação e saúde. Nos Estados Unidos, instituiu-se um modelo em que as identidades equivalem-se como etnicidades; são sujeitos imiscíveis de direitos. O espaço público é percebido como fragmentado em grupos de descendência que não se mesclam entre si. Logo, nos casos norte-americano e argentino, por motivos diferentes, haveria como que uma cegueira para a miscigenação, ao contrário do que acontece no Brasil. A assimilação da posição do outro tornou-se a positividade do ser brasileiro. A instituição desse imaginário nacional, lembramos, teve como momento fundamental a admissão de Casa Grande \& Senzala, de Gilberto Freyre, como ideologia nacionalista a partir da Era Vargas. Por consequência, criou-se no Brasil uma ênfase na identidade da nação pela mistura cultural e étnica, e, por outro lado, uma profunda dificuldade em resolver o conflito e a desigualdade.

O foco na temática da constituição da nacionalidade leva a autora, em outros momentos, a uma análise mais diacrônica. Estabelecendo diálogos entre geografia, psicanálise, ciência política e filosofia, Segato aponta como diferentes modos de governabilidade na história do Ocidente relacionaram as noções de poder, território e soberania. Atenta aos termos correntes utilizados para descrever o momento histórico atual, como "choque de civilizações", "globalização" ou "destradicionalização", a autora prefere descrever o momento atual pelo surgimento de novas formas de produção da territorialidade, calcada menos em conteúdos aprofundados, que em marcas identitárias superficiais e desvinculada da correspondência a um espaço geográfico preciso. A fragmentação da nação e o esvaziamento dos debates públicos estariam associados a essa nova forma de constituir o espaço social. A expansão do pentecostalismo na América Latina sinalizaria essa mudança, na medida em que a identidade dos evangélicos, como povo de Deus, atravessa as fronteiras e fornece, mesmo a partir de denominações e realidades nacionais variadas, uma ancoragem identitária comum, fundamentada em 
pautas de política moral. Tomando essas pautas (moralização da política, combate à descriminzalização do aborto e ao reconhecimento dos direitos civis dos homossexuais) como bandeiras, parte das denominações pentecostais passa atualmente a se reivindicar como força política, num cenário em que o poder pastoral deixa de ser monopólio discursivo do Estado e se dispersa.

Por outro lado, a difusão das religiões de matriz cultural africana na região revela uma dinâmica distinta, de reetnificação, dado que o reconhecimento público dessas expressões religiosas está atrelado à valorização de uma forma cultural e a uma territorialidade distinta da pentecostal. Todo o sistema de crenças remete à mitopraxisde um povo em diáspora. O território instaurado pelos cultos condensa a África mítica e o chão das senzalas, de tal maneira que a iniciação imbrica a história pessoal do neófito a experiência histórica de sofrimento. Embora não estejam explicitados no livro, a discussão de certos temas como a relação de agentes religiosos de matriz africana com a política ou com os políticos em distintos países, e as recentes interferências de setores diversos em aspectos centrais dos seus cultos (principalmente no tocante ao sacrifício de animais) se beneficiaria com um enquadramento no cenário de "faccionalização da república”.

A instauração de novas identidades políticas, fundada na apologia da diferença, em voga atualmente nas humanidades e nas políticas públicas, não necessariamente implica novas dinâmicas políticas. Como focos de análise, Segato sugere que observemos a insurgência de novos movimentos identitários e de reivindicação de direitos, a partir de sua relação dentro do contexto das formações nacionais de alteridade específicas, sua lógica interna, sua relação com atores sociais locais e transnacionais e sua posição diante do todo. Movimentos sociais que fundam sua identidade em alteridades constituídas nos/pelos modernos Estados nacionais nem sempre espelham a complexidade das relações históricas que reivindicam. Podem levar mesmo a uma "pasteurização" da diferença, subsumindo a dimensão subjetiva do pertencimento a sinais diacríticos superficiais e ao pragmatismo político. A autora interpreta que, nos Estados Unidos, esse modelo de, diríamos, "comoditização" da alteridade foi levado ao extremo, e essa mesma linguagem de divisão da sociedade civil por diferenças emblemáticas tem sido adotado no Sul. Ainda assim, Segato acredita que, na América Latina, haveria 
condições mais propícias de desenvolver a densidade histórica e simbólica da "diferença radical".

Por fim, salientamos a importância de um livro como o de Segato, para os que hoje estudam redes transnacionais de agentes religiosos. A nosso ver, o estudo de religiões que atravessam fronteiras nacionais não pode estar descolado de uma discussão sobre as formações de alteridade em jogo e sobre as forças políticas hegemônicas no cenário internacional. Recordamos que, há quase um século atrás, houve na Antropologia anglo-saxã uma recusa ao difusionismo cultural, que centralizava as descobertas mais importantes da humanidade em civilizações específicas, principalmente no antigo Egito. Em seu lugar, foram propostos estudos monográficos de cunho funcionalista que influenciam nosso modo de fazer Antropologia até hoje. Com a emergência dos estudos sobre globalização, tornase necessário recolocar certos aspectos metodológicos, relativizando a equivalência postulada pela tradição da política internacional entre espaço social e espaço geográfico e assumindo as transversalidades como objeto, mas sem perder de vista que seus vetores não são aleatórios. Essa visão dos processos de transnacionalização religiosa frente às formações de alteridade como uma "guerra de posições" a la Gramsci, sem perder de vista a experiência subjetiva dos atores, parece-nos uma contribuição importante a ser examinada no livro La Nación y Sus Otros. 